\title{
Studies on Persistent Organic Pollutants in the Lagos Lagoon ii: Evaluation and Spatial Distribution of Polycyclic Aromatic Hydrocarbons in Sediments of the Lagoon
}

\author{
Alani Rose ${ }^{1, ~ *, ~ D r o u i l l a r d ~ K e n ~}{ }^{2}$, Olayinka Kehinde ${ }^{1}$, Alo Babajide ${ }^{1}$ \\ ${ }^{1}$ Chemistry Department, University of Lagos, Nigeria \\ ${ }^{2}$ Great Lakes Institute for Environmental Research (GLIER), University of Windsor, Wndsor, Ontario, Canada
}

Email address:

ralani@unilag.edu.ng (A. Rose),kgd@uwindsor.ca (D. Ken), keolayi20002000@yahoo.com (O. Kehinde), profjidealo@yahoo.com (A. Babajide)

${ }^{*}$ Corresponding author

To cite this article:

Alani Rose, Drouillard Ken, Olayinka Kehinde, Alo Babajide. Studies on Persistent Organic Pollutants in the Lagos Lagoon ii: Evaluation and Spatial Distribution of Polycyclic Aromatic Hydrocarbons in Sediments of the Lagoon. International Journal of Environmental Monitoring and Analysis. Vol. 5, No. 2, 2017, pp. 56-63. doi: 10.11648/j.ijema.20170502.16

Received: January 6, 2017; Accepted: January 24, 2017; Published: March 28, 2017

\begin{abstract}
PAHs in the Lagos lagoon are high enough to raise concern over possible adverse effects on aquatic organisms and human health. Their spatial distribution in the sediment was largely dependent on the proximity of the sediment deposition site to known sources of pollution. Due to their tendency to accumulate in sediments at the bottom of the food chain, PAHs in the lagoon could pose a toxicological threat to benthic organisms and their predators. In this study, the PAH levels in the sediments of the lagoon at twelve locations were evaluated. This work is a follow-up on an earlier paper showing the levels of PAHs in the water samples of the lagoon. All sixteen EPA priority PAHs were found in eight of the locations. Significant amounts of most of the PAHs were found in all the sediments throughout the year. The higher PAHs were more abundant and distributed across the lagoon. Bioavailability assessment revealed that the PAHs were not bioavailable. Adjusted Equilibrium Sediment Benchmark Toxic Units $\Sigma$ ESBTU revealed that the lagoon sediments at all the locations were not toxic to aquatic life.
\end{abstract}

Keywords: Lagos Lagoon, Sediment, Polycyclic Aromatic Hydrocarbons, ESBTUs

\section{Introduction}

Polycyclic Aromatic Hydrocarbons are organic compounds composed of two or more benzene rings. As the molecular weight of these compounds increases, solubility in lipids increases and resistance to oxidation and reduction decreases [1].

PAHs vary in their behavior and biological effects, the lower molecular weight PAHs (2- and -3- ring compounds) tend to be more water soluble, more volatile, more readily metabolized and more persistent, whereas higher molecular weight PAHs (4 -7 - ring compounds) are less water soluble, less volatile, less readily metabolized and more persistent as reported by [1].

PAHs occur naturally in bituminous fossil fuels, such as coal and crude oil deposits, as a result of diagnosis. Volcanic activity and biosynthesis by bacteria and plants are other natural sources of PAHs. According to [2], environmental sources of PAHs of Pyrolitic origin are many. These sources include terrigenous, urban, and riverine inputs, industrial, agricultural, sewage discharges, atmospheric deposition, shipping traffic and other anthropogenic inputs [3] and [4]. Other sources which include algae, phytoplankton, and zooplankton were also reported by [1].

Evidence abound that anthropogenic activities such as petroleum refining, disposal of municipal and domestic sewage etc, contribute to the distribution of PAHs contaminants i.

PAHs are distinct from other Persistent Organic Pollutants (POPs) like Polychlorinated Biphenyls (PCBs), 
Organochlorine Pesticides, Dioxins and Furans. The most important distinction as observed by [5] is that significant sources of PAHs continue to generate these chemicals and release them into the environment. The Lagos lagoon, the study area, receives loads from a number of creeks, drainage systems and important large rivers (Yewa, Ogun, Ona and Oshun), draining more than $103,26 \mathrm{~km}$ of the country [6]. Lagos lagoon is an important habitat for a wide array of fish and marine organisms and these serve as a major source of protein for the inhabitants of Lagos. A study by [7] revealed that rivers generally constitute a significant transport route for pollutants from their sources into the Marine environment and PAHs are ubiquitous constituents of estuarine sediments.

The city of Lagos has about 91 water- ways (canals) and their tributaries deflooding the entire city and discharging into the lagoon at different locations. The highest contributions of PAHs are generally found around urban areas [8], as urban runoff contains almost every type of water pollutant including suspended solids, bacteria, heavy metals, organics, nutrients, oil and grease etc. and densely populated areas, (greater part of Lagos) produce the highest loads. Estimated sediments from non-point sources to be 360 times the point source load [9]. Increasing amount of urban sprawl and vehicle traffic in urban and suburban areas also contribute highly to increasing trends in PAH concentrations [10].

In view of its complexity (linkages to land, freshwater, sea, salinity fluctuations, dynamics) the lagoon is a fragile ecosystem prone to environmental degradation through pollution from industry, household, resource overexploitation etc. The estimated area of the lagoon is $150.56 \mathrm{~km}^{2}$ while the harbor is about $8 \mathrm{~km}$ long and leads to the wharf area of Apapa where shipping and other oil related activities are concentrated, figure 1. Several other activities such as industrial and municipal waste disposal, open incineration of wastes, open burning of saw dusts, untreated sewage disposal etc. are common sights within Lagos and along the shores of the lagoon, figure 1 .

The above activities contribute highly to the presence of PAHs in Lagos environment as a whole and Lagos lagoon sediment in particular, going by the report of [11] that PAHs are ubiquitous constituents of estuarine sediments. Both natural/petrogenic and anthropogenic activities generate PAHs in the environment. A study by [10] revealed that uncombusted sources (e.g. oil seeps petroleum spills) contain predominantly two - and three - ringed compounds whereas combustion (e.g. automobiles, domestic heating with coal, forest fires etc.) results in predominantly four to six ringed species. Among sources of PAHs related to automobiles are tire wear, crankcase oil, roadway wear, and car soot and exhaust [12]. Incomplete combustion of organic matter at high temperatures is one of the major anthropogenic sources of environmental PAHs. PAH concentrations on coal- and wood - derived particles have been found to be several orders of magnitude higher than on silica particles. $5 \%$ of coal/wood-derived particles in sediment by weight contain $65 \%$ of the total PAHs, the remaining $38 \%$ being mainly from the clay and silt fraction [13]. Petroleum is introduced into the lagoon at the harbor either as a relatively thin film or as floating or suspended particles. Though benthic community, especially the large ones are able to withstand percentile concentrations of oil in the sediment; mortality can be high amongst fish [14]. Sediments from the lagoon receive inputs of organic material from a wide variety of sources. As a result of these variations in sources, there's high spatial and temporal variability of constituents (PAH in particular) in surface sediment throughout the lagoon [15].

Since sediment represents a sink for lipophilic pollutants as PAHs, it is therefore an ideal matrix for chemical analysis. Sediments represent an assessment tool, where sediment quality guidelines can be used in a first tier approach, to examine the quality of the environment [16] and [17].

In this study, sixteen USEPA priority PAHs (table 1) were analyzed for in sediment samples from 12 locations on the lagoon. Many PAHs are inducers of cytochrome P450s and thus resulting in mutagenic and carcinogenic effects [18]. The larger compounds (five or more rings) are not only difficult to biodegrade but also tend to be carcinogenic [19]. Exposure of marine organisms to PAH can cause deleterious effects at the site of contact via the circulatory system, various organs and tissues [20]. Their significant availability in the sediments of Lagos lagoon is a matter of great concern. As part of our on-going studies on the Gulf of Guinea and the Lagoons of the region, it was considered necessary to investigate the levels of POPs in the Lagos Lagoon. The aim of this study was therefore to trace the sources, the level and the spatial distribution of PAHs in the sediments of Lagos lagoon as a corollary to our earlier study of PAHs in the Lagos Lagoon water system.

\section{Materials and Mathods}

\subsection{Sample Collection and Preparation}

Sediment samples were collected in February 2004 from the 11 locations on the Lagos lagoon, (Figure 1). All reagents used were of pesticide analysis grade (or equivalent). Sample extractions were carried out according to [21] \& [22]. Moisture and organic carbon contents of the sediments were also determined. Sample extracts obtained after florisil cleanup were combined and rotoevaporated to $1 \mathrm{ml}$ and analyzed for Polycyclic Aromatic Hydrocarbons (PAHs) by gas chromatography. 


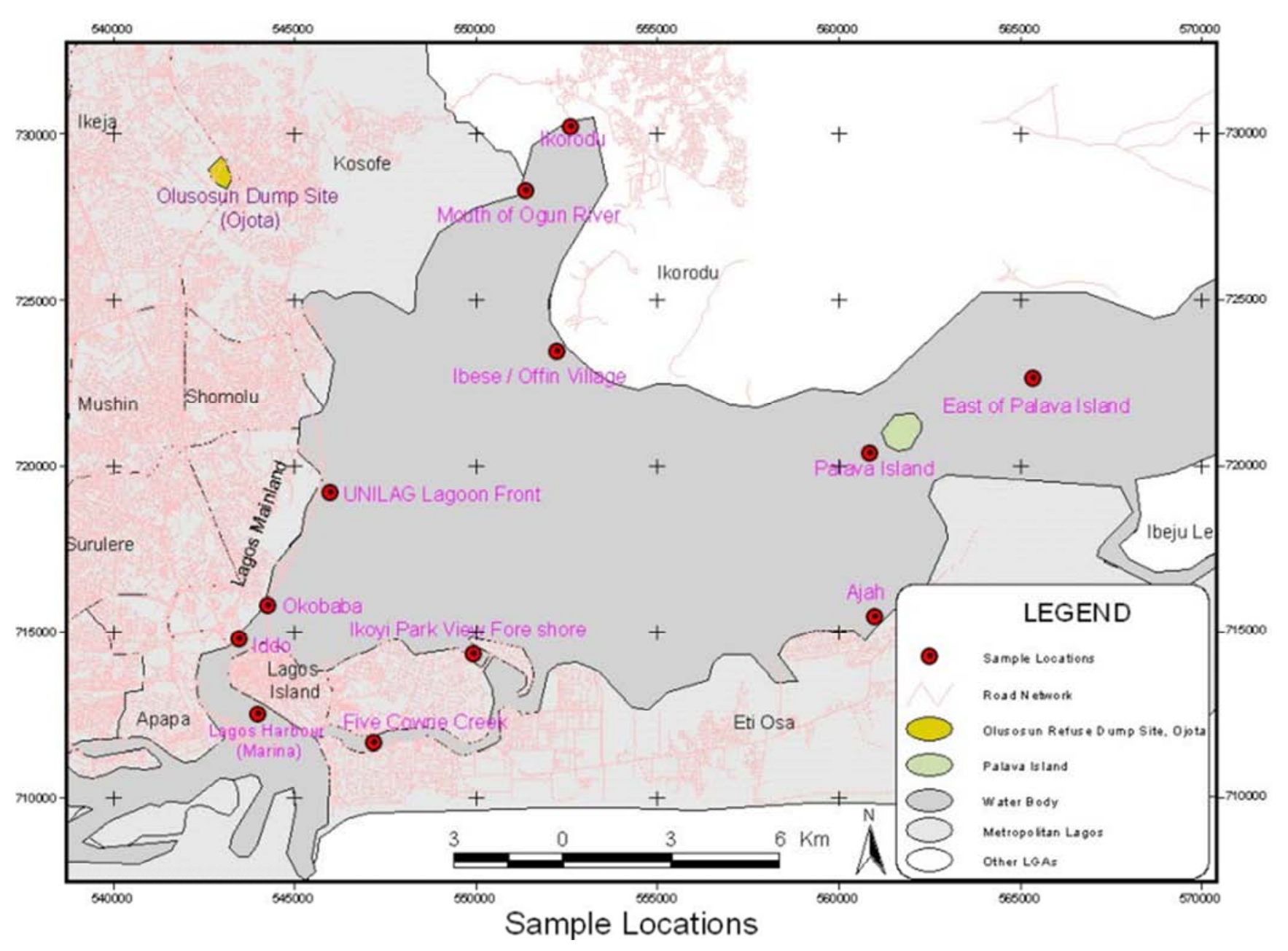

Figure 1. Map of Lagos lagoon showing the sample locations and areas of human activities.

\subsection{Sample Analysis}

Analysis was run on a Hewlett- Packard (Avondale, PA) Model 5890/5970 Gas Chromatograph with a mass selective detector (quadrupole mass analyzer, $70 \mathrm{eV}$ ) equipped with a Hewlett-Packard $7673 \mathrm{~A}$ autosampler and a $30 \mathrm{~m} \times 0.25 \mathrm{~mm}$. I. D. X $0.10 \mu \mathrm{m}$ DB-5 film thickness column. $1 \mu$ l sample was injected using a splitless injection mode at $250^{\circ} \mathrm{C}$ injection temperature and GC-MSD interface temperature of $280^{\circ} \mathrm{C}$. A mixture of three 13C-labelled PCBs (13C - PCB 52, 13C PCB 153 and 13C - PCB 37) was used as surrogate standard. The PAHs were identified and quantified by comparison of retention times and spectra of internal standards. Concentrations were not corrected for the recovery of internal standards. Some of the compounds, for instance, Naphthalene were found in the method blanks but during integration all the concentrations found in the blank were removed from the samples. PAH concentrations were reported on a dry weight basis.

\section{Results and Discussions}

The PAHs were found to be distributed across the entire lagoon. The distributions of organic contaminants in sediments are strongly related to their physico-chemical properties (mainly hydrophobicity) [23].

The results revealed that the appearance of the sediments is a poor indicator of individual PAH concentrations. For instance, sediment from Okobaba $\left(\mathrm{B}_{3}\right)$, a site where saw dust was openly burnt and discharged directly into the lagoon, was the darkest in colour but did not have the highest PAH concentrations. Attempts to quantify the relationship between black smoke and individual PAH revealed that PAHs are just an integral part of soot because they are both formed during combustion. In their pure state many of the PAHs of interest (benzo (a) pyrene, benzo (e) pyrene, benzo (a) anthracene, pyrene, fluoranthene etc) are white crystalline solids. The blackness only arises because they are absorbed onto, and thereby intimately mixed with, black soot particles. Locations E and E2 had much darker sediments than that of Five cowrie creek which was just white sand but their PAH concentrations were far lower than what was obtained in Five cowrie creek. The Lagos lagoon sediments were typically highly mixed.

\subsection{Spatial Distribution of PAHs}

Table 1 revealed that lower molecular weight PAHs were more abundant in the Lagos lagoon sediments. Lower molecular weight PAHs (2- and -3- ring compounds) tend to 
be more water soluble, more volatile, more readily metabolized and less persistent, whereas higher molecular weight PAHs (4 -7 - ring compounds) are less water soluble, less volatile, less readily metabolized and more persistent.

Table 1. Sediment PAHs at Eleven Locations on Lagos lagoon in April 2004.

NAME OF PAH
1. Naphthalene

It was observed that only Ikoyi park view fore shore (location C) had all the sixteen EPA priority PAHs (tables 1 $\& 2$ ). This location is far from high human activities and mainly residential but the main activity is dredging. Palava Island (E) and East of Palava Island had the least number (4 each) and lowest concentrations of PAHs (table 2). Between eleven and fifteen PAHs were found in the remaing nine locations. Naphthalene, phenanthrene, fluoranthene, pyrene, and chrysene were found in all the locations. The role of sediments in retention of PAHs in the environment is of importance to bottom dwelling fish. "[15], states that many
PAHs such as naphthalene and phenanthrene are actually toxic at whole body concentrations above 50,000ppm and deleterious response occur at concentration in the range 100 $-5000 \mathrm{ppm}$ "

The concentration of the PAHs in the lagoon sediments was dependent mostly on the input from the different point sources such as the Lagos harbor (Petrogenic source), Okobaba (Pyrogenic source), Iddo (point of many anthropogenic sources), and so many other locations along the shores of the lagoon. Also great contributions came from a network of drainage channels (canals etc) which drained organics and all forms of pollutants from all over the city and discharged them to the lagoon at several locations. Lagos harbor (A3), where shipping and oil- related activities are concentrated, was expected to have one of the highest concentrations of total PAHs (especially the LMW PAHs) but rather it was one of the locations with comparatively low total PAH concentrations. Petrogenic PAHs are mainly the LMW PAHs according to [10] who reported that uncombusted sources of PAHs (e.g. oil seeps petroleum spills) contain predominantly two - and three - ringed compounds whereas combustion sources (e.g. automobiles, domestic heating with coal, forest fires etc.) result in predominantly four to six ringed species.

The low PAH concentrations at the harbor was possibly due to the fact that the PAHs at this location are oil based and could easily be transported from the source point by floating rather than sinking down immediately to the bottom sediment. Oil degradation and dissipation at the harbor also possibly contributed to the low PAH levels obtained at that location. The wave actions of the lagoon also contributed to the drift in the deposition of some of the petrogenic PAHs to the locations close by, and subsequently to the entire lagoon. Just about $2.5 \mathrm{~km}$ away from the harbor (location $\mathrm{A}_{3}$ ) is the Five-cowrie creek (location $\mathrm{A}_{2}$ ), which equally had 15 PAHs just as the harbor. Five cowrie creek is a $3.1 \mathrm{~km}$ long distributary flowing from the Lagos lagoon at Banana Island and linking the harbour between Ring road and Ozumba Mbadiwe Avenue. The creek is impacted by the third mainland, Falomo and Bonny Camp bridges. Main activities fishing and transport businesses. The PAHs at this location were likely from several anthropogenic sources, including automobile exhausts from the bridges passing the Five-cowrie creek and the drift from the harbor. As the wave actions carried the floating oil away, attachment to particles could occur in the process and subsequently a gradual deposition of the PAH loaded particles at distance (around Five cowrie creek) not too far from the source. Also volatilization from the water surface and condensation at other locations on cooling possibly enhanced the transporting of the PAHs from the point of petrogenic source. Several interacting and competing processes possibly occurred to either degrade the oil or transport it with the PAHs from the harbor to other locations on the lagoon by wave actions. 
Table 2. PAH ranges in the Sediment Samples of the Lagos Lagoon in the Year 2004.

\begin{tabular}{|c|c|c|c|c|c|c|c|c|c|c|c|c|c|}
\hline & $\mathbf{A}$ & A2 & A3 & B2 & B3 & C & $\mathrm{C} 2$ & D & D2 & $\mathbf{E}$ & E2 & $\begin{array}{l}\text { ISQG } \\
{[27]} \\
\end{array}$ & $\begin{array}{l}\text { PEL [26] } \\
\text { and [27] }\end{array}$ \\
\hline Total PAHs (ng/g) & 1093 & 149.98 & 189.17 & 118.26 & 509.5 & 151.1 & 70.24 & 670.13 & 198.4 & 3.46 & 3.48 & & \\
\hline NA & 26.61 & 2.0096 & 6.8854 & 13.479 & 34.71 & 16.33 & 23.35 & 6.93 & 55.01 & & & 34.6 & 391 \\
\hline $\mathrm{AL}$ & & 1.2135 & 0.2692 & & 2.205 & 0.494 & 0.304 & & & & & 6.71 & 88.9 \\
\hline $\mathrm{AE}$ & 0.028 & 0.5619 & 0.479 & & & 1.067 & 0.628 & 4.4342 & 8.443 & & & 5.87 & 128 \\
\hline FL & 1.767 & & & 0.2628 & 3.263 & 0.55 & 0.838 & 3.2646 & 2.748 & & & 21.2 & 144 \\
\hline PHE & 11.52 & 7.8844 & 13.152 & 7.5381 & 33.41 & 10.85 & 10.42 & 45.052 & 10.79 & 2.01 & 2.02 & 113 & 1494 \\
\hline AN & & 0.7657 & 1.8776 & & 14.39 & 2.399 & & 5.3969 & 0.357 & & & 86.7 & 544 \\
\hline FLT & 7.732 & 26.196 & 20.209 & 17.289 & 64.52 & 15.05 & 7.668 & 131.18 & 23.9 & 0.81 & 0.82 & 46.9 & 245 \\
\hline PY & 8.654 & 25.251 & 21.355 & 18.029 & 109.8 & 24.86 & 7.864 & 117.48 & 30.03 & 0.23 & 0.23 & 153 & 1398 \\
\hline $\mathrm{B}(\mathrm{a}) \mathrm{A}$ & 0.844 & 8.8619 & 13.256 & 9.155 & 38.92 & 8.192 & 1.738 & 67.678 & 14.85 & & & 108 & 846 \\
\hline Chrysene & 25.34 & 18.608 & 14.485 & 11.252 & 38.89 & 7.629 & 2.93 & 62.724 & 13.64 & 0.41 & 0.41 & 74.8 & 693 \\
\hline $\mathrm{B}(\mathrm{b}) \mathrm{F}$ & 1.583 & 12.395 & 21.512 & 11.939 & 40.44 & 12.15 & 0.462 & 51.629 & 14.67 & & & - & - \\
\hline $\mathrm{B}(\mathrm{k}) \mathrm{F}$ & 1.151 & 8.5402 & 14.697 & 9.3564 & 24.93 & 9.28 & 0.334 & 41.429 & 9.962 & & & - & - \\
\hline $\mathrm{B}(\mathrm{a}) \mathrm{P}$ & *997.4 & 13.804 & 22.397 & 13.1 & 39.92 & 14.83 & 13.69 & 52.386 & 11.28 & & & 88.8 & 763 \\
\hline IP & 10.4 & 9.499 & 17.087 & 6.862 & 26.61 & 11.62 & & 41.416 & 2.727 & & & - & - \\
\hline $\mathrm{D}(\mathrm{ah}) \mathrm{A}$ & & 1.5782 & 2.1156 & & 2.458 & 0.906 & & 7.2296 & & & & 6.22 & 135 \\
\hline $\mathrm{B}$ (ghi)P & & 12.813 & 19.395 & & 34.95 & 14.87 & & 31.891 & & & & - & - \\
\hline TUP & 39.93 & 12.435 & 22.664 & 21.28 & 87.99 & 31.69 & 35.55 & 65.078 & 77.35 & 2.01 & 2.02 & & \\
\hline TCP & 1053 & 137.54 & 166.51 & 96.982 & 421.5 & 119.4 & 34.69 & 605.05 & 121.1 & 1.45 & 1.46 & & \\
\hline $\begin{array}{l}\text { Ratio of TUP to } \\
\text { TCP }\end{array}$ & 0.038 & 0.0904 & 0.1361 & 0.2194 & 0.209 & 0.266 & 1.025 & 0.1075 & 0.639 & 1.39 & 1.39 & & \\
\hline
\end{tabular}

- Concentrations exceeding both Interim marine sediment quality guidelines (ISQGs) and probable effect levels (PELs; dry weight) while concentrations exceeding only PELs are highlighted in table 2

- TUP is Total Uncombusted PAHs and TCP is Total Combustion PAHs

Sediments from Iddo (A), Okobaba (B3) and Mouth of Ogun River (D) had the highest total PAHs of 1093, 670.13 and $509.5 \mathrm{ng} / \mathrm{g}$ respectively (table 2). Iddo is a very busy, highly populated reisdential and industrial area Okobaba is a heavily populated slum settlement close to Iddo. This location is impacted by the third mainland Bridge. And the main activity is wood related business and constant burning of sawdust takes placeat this location. As observed by [24] the largest release of PAHs is through atmospheric fallouts during incomplete combustion of organic compounds. The Mouth of Ogun River is a fluvial source which drains more than $103 \mathrm{~km}$ of the country into the Lagos lagoon. The high risk observed at this location is in agreement with [25] who reported high PAH concentrations as evidence for the influence of local pollution sources, such as river input (the Odra to the Pomeranian Bay and the Vistula to the Gulf of Gdańsk).. All the other locations have less activities than these three.

As shown in table 2 , the ratios of TUP/TCP $<1$ were obtained at most of the locations except at Aja (C), Palava Island (E) and East of Palava Island (E2). Larger ratios indicated the dominance of natural and fuel related PAHs (uncombusted) whereas smaller ratios indicated the dominance of combustion-related PAHs. Total PAHs primarily from uncombusted sources includes 2- and 3ringed compounds such as Naphthalene, Acenaphthylene, Acenaphthene, Fluorene, Anthracene, and Phenanthrene while the total major-combustion PAHs includes $4-7$ ringed compounds [10]. This result indicated that the occurrence and distribution of PAHs in the Lagos lagoon environment in February 2004 was largely a result of incomplete combustion, except at Aja, Palava Island and East of Palava Island where PAH distribution were predominantly from petrogenic and natural sources. Unfortunately, carcinogenic PAHs all fall in the high molecular weight category, having four or more rings. These chemicals can cause cancer through their direct interaction with DNA. Benzo(a)pyrene, which is a known carcinogen was found in an alarming concentration $(997.40 \mathrm{ug} / \mathrm{g})$ in the sediment at Iddo (table 2).

\subsection{Sediment PAH Evaluation}

Naphthalene, acenaphthene, fluoranthene and dibenzo $(\mathrm{a}, \mathrm{h})$ anthracene were found to exceed the interim marine sediment quality guidelines (ISQGs). Though total PAHs indicated no threat to human health, assessment of individual PAHs based on interim marine sediment quality guidelines (ISQGs) of $88.9 \mathrm{ug} / \mathrm{Kg}$ and probable effect levels (PELs; dry weight) of $763 \mathrm{ug} / \mathrm{Kg}$ [26], has identified Iddo as having benzo(a)pyrene at level $(997.4 \mathrm{ng} / \mathrm{g}$ dry weigh, exceeding both ISQGs and PELs) that poses a risk to the environment. Studies by [28] have shown that benzo (a) pyrene (BaP) can be accumulated to potentially hazardous levels in fish and invertebrates. The formation of reacting intermediates, such as diol and phenol epoxides of $\mathrm{BaP}$ have been implicated in mutagenesis and carcinogenesis of mammals. $\mathrm{BaP}$ is among the most toxic PAH compounds, causing deleterious effects at whole body concentrations above $100 \mathrm{ppm}$ Iddo, a very highly populated reisdential and industrial area, is the most busy of the 12 sample areas. 
Table 3. Normalized PAH concentrations $\left(n g / g_{o c}\right)$ at different locations.

\begin{tabular}{|c|c|c|c|c|c|c|c|c|c|c|c|c|}
\hline & $\mathbf{A}$ & A2 & A3 & B2 & B3 & $\mathrm{C}$ & $\mathrm{C} 2$ & D & D2 & $\mathbf{E}$ & E2 & FCV \\
\hline$f_{o c}$ & 0.0619 & 0.0028 & 0.0563 & 0.0407 & 0.1166 & 0.1652 & 0.1106 & 0.027 & 0.1415 & 0.0063 & 0.0102 & \\
\hline NA & 429.93 & 717.74 & 122.3 & 331.17 & 297.702 & 98.852 & 211.16 & 256.67 & 388.74 & & & 385000 \\
\hline $\mathrm{AL}$ & & 433.4 & 4.7818 & & 18.9126 & 2.9913 & 2.747 & & & & & 452000 \\
\hline $\mathrm{AE}$ & 0.4529 & 200.71 & 8.5076 & & & 6.4558 & 5.6754 & 164.23 & 59.668 & & & 491000 \\
\hline FL & 28.55 & & & 6.4572 & 27.9874 & 3.3277 & 7.5752 & 120.91 & 19.421 & & & 538000 \\
\hline PHE & 186.15 & 2815.9 & 233.61 & 185.21 & 286.566 & 65.696 & 94.246 & 1668.6 & 76.256 & 319.098 & 198.482 & 596000 \\
\hline AN & & 273.47 & 33.35 & & 123.442 & 14.519 & & 199.89 & 2.5261 & & & 594000 \\
\hline FLT & 124.91 & 9356 & 358.96 & 424.79 & 553.346 & 91.11 & 69.329 & 4858.6 & 168.92 & 128.724 & 80.0675 & 707000 \\
\hline PY & 139.8 & 9018.3 & 379.31 & 442.98 & 942.002 & 150.47 & 71.107 & 4351.4 & 212.26 & 36.4025 & 22.6427 & 697000 \\
\hline B(a)A & 13.641 & 3165 & 235.45 & 224.94 & 333.746 & 49.59 & 15.713 & 2506.6 & 104.97 & & & 841000 \\
\hline Chrysene & 409.42 & 6645.9 & 257.28 & 276.46 & 333.516 & 46.181 & 26.493 & 2323.1 & 96.384 & 64.8505 & 40.3376 & 844000 \\
\hline $\mathrm{B}(\mathrm{b}) \mathrm{F}$ & 25.576 & 4426.8 & 382.09 & 293.33 & 346.863 & 73.52 & 4.1729 & 1912.2 & 103.67 & & & 979000 \\
\hline $\mathrm{B}(\mathrm{k}) \mathrm{F}$ & 18.599 & 3050.1 & 261.05 & 229.89 & 213.769 & 56.172 & 3.0209 & 1534.4 & 70.406 & & & 981000 \\
\hline $\mathrm{B}(\mathrm{a}) \mathrm{P}$ & 16113 & 4930.3 & 397.82 & 321.86 & 342.382 & 89.784 & 123.8 & 1940.2 & 79.714 & & & 965000 \\
\hline IP & 168.02 & 3392.5 & 303.51 & 168.6 & 228.184 & 70.316 & & 1533.9 & 19.271 & & & 1115000 \\
\hline $\mathrm{D}(\mathrm{ah}) \mathrm{A}$ & & 563.66 & 37.578 & & 21.0801 & 5.4869 & & 267.76 & & & & 1123000 \\
\hline B(ghi)P & & 4576.2 & 344.5 & & 299.738 & 90.001 & & 1181.2 & & & & 1095000 \\
\hline
\end{tabular}

The bioavailability of the PAHs was estimated using Equilibrium Partitioning Sediment Benchmarks (ESBs). To develop ESBs for sediment for Polycyclic Aromatic Hydrocarbons (PAHs), the Total Organic Carbon (TOC) content of the sediment was used to normalize the amount of PAH per gram of organic carbon. This was then compared against the Final Chronic Value (FCV) for the PAHs (table 3 ). The result showed that the Mouth of Ogun River (D) and
Five cowrie creek (A2) had high concentrations of PAHs but none exceeded the FCV (table 3 ). This indicated that none of the PAHs was bioavailable.

ESB Toxic Unit (ESBTU) was then determined by dividing the normalized concentration for each $\mathrm{PAH}$ calculated in table 3 by its corresponding Final Chronic Value $(\mathrm{FCV})$ found in table 3.

Table 4. Equilibrium Sediment Benchmark Toxic Units (ESBTUs).

\begin{tabular}{|c|c|c|c|c|c|c|c|c|c|c|c|c|}
\hline & FCV & $\mathbf{A}$ & A2 & A3 & B2 & B3 & $\mathrm{C}$ & $\mathrm{C2}$ & D & D2 & $\mathbf{E}$ & E2 \\
\hline NA & 385000 & 0.0011 & 0.0019 & 0.0003 & 0.0009 & 0.0008 & 0.0003 & 0.0005 & 0.0007 & 0.001 & 0 & 0 \\
\hline AL & 452000 & 0 & 0.001 & $1 \mathrm{E}-05$ & 0 & $4 \mathrm{E}-05$ & $7 \mathrm{E}-06$ & $6 \mathrm{E}-06$ & 0 & 0 & 0 & 0 \\
\hline $\mathrm{AE}$ & 491000 & 9E-07 & 0.0004 & $2 \mathrm{E}-05$ & 0 & 0 & $1 \mathrm{E}-05$ & 1E-05 & 0.0003 & 0.0001 & 0 & 0 \\
\hline FL & 538000 & $5 \mathrm{E}-05$ & 0 & 0 & $1 \mathrm{E}-05$ & $5 \mathrm{E}-05$ & $6 \mathrm{E}-06$ & $1 \mathrm{E}-05$ & 0.0002 & $4 \mathrm{E}-05$ & 0 & 0 \\
\hline PHE & 596000 & 0.0003 & 0.0047 & 0.0004 & 0.0003 & 0.0005 & 0.0001 & 0.0002 & 0.0028 & 0.0001 & 0.0005 & 0.0003 \\
\hline AN & 594000 & 0 & 0.0005 & $6 \mathrm{E}-05$ & 0 & 0.0002 & $2 \mathrm{E}-05$ & 0 & 0.0003 & 4E-06 & 0 & 0 \\
\hline FLT & 707000 & 0.0002 & 0.0132 & 0.0005 & 0.0006 & 0.0008 & 0.0001 & 1E-04 & 0.0069 & 0.0002 & 0.0002 & 0.0001 \\
\hline PY & 697000 & 0.0002 & 0.0129 & 0.0005 & 0.0006 & 0.0014 & 0.0002 & 0.0001 & 0.0062 & 0.0003 & $5 \mathrm{E}-05$ & $3 \mathrm{E}-05$ \\
\hline B(a)A & 841000 & $2 \mathrm{E}-05$ & 0.0038 & 0.0003 & 0.0003 & 0.0004 & $6 \mathrm{E}-05$ & 2E-05 & 0.003 & 0.0001 & 0 & 0 \\
\hline C\&T & 844000 & 0.0005 & 0.0079 & 0.0003 & 0.0003 & 0.0004 & $5 \mathrm{E}-05$ & $3 \mathrm{E}-05$ & 0.0028 & 0.0001 & $8 \mathrm{E}-05$ & $5 \mathrm{E}-05$ \\
\hline $\mathrm{B}(\mathrm{b}) \mathrm{F}$ & 979000 & $3 \mathrm{E}-05$ & 0.0045 & 0.0004 & 0.0003 & 0.0004 & $8 \mathrm{E}-05$ & 4E-06 & 0.002 & 0.0001 & 0 & 0 \\
\hline $\mathrm{B}(\mathrm{k}) \mathrm{F}$ & 981000 & $2 \mathrm{E}-05$ & 0.0031 & 0.0003 & 0.0002 & 0.0002 & $6 \mathrm{E}-05$ & $3 \mathrm{E}-06$ & 0.0016 & 7E-05 & 0 & 0 \\
\hline $\mathrm{B}(\mathrm{a}) \mathrm{P}$ & 965000 & 0.0167 & 0.0051 & 0.0004 & 0.0003 & 0.0004 & 9E-05 & 0.0001 & 0.002 & $8 \mathrm{E}-05$ & 0 & 0 \\
\hline IP & $1 \mathrm{E}+06$ & 0.0002 & 0.003 & 0.0003 & 0.0002 & 0.0002 & $6 \mathrm{E}-05$ & 0 & 0.0014 & 2E-05 & 0 & 0 \\
\hline $\mathrm{D}(\mathrm{ah}) \mathrm{A}$ & $1 \mathrm{E}+06$ & 0 & 0.0005 & $3 \mathrm{E}-05$ & 0 & $2 \mathrm{E}-05$ & $5 \mathrm{E}-06$ & 0 & 0.0002 & 0 & 0 & 0 \\
\hline $\mathrm{B}$ (ghi)P & $1 E+06$ & 0 & 0.0042 & 0.0003 & 0 & 0.0003 & $8 \mathrm{E}-05$ & 0 & 0.0011 & 0 & 0 & 0 \\
\hline$\sum$ ESBTU & & 0.0193 & 0.0667 & 0.0041 & 0.004 & 0.0059 & 0.0013 & 0.0011 & 0.0314 & 0.0024 & 0.0008 & 0.0005 \\
\hline $\begin{array}{l}\sum \mathrm{ESBTU} \\
* \mathrm{UF}\end{array}$ & & 0.2214 & 0.7669 & 0.0474 & 0.0464 & 0.0679 & 0.0144 & 0.0129 & 0.3615 & 0.0271 & 0.0097 & 0.0061 \\
\hline
\end{tabular}

- FCV means Final Chronic Value, UF means Uncertainty Factor

Adjusted $\Sigma$ ESBTU was used to determine whether the sediment was toxic to the aquatic life. This was obtained by multiplying the selected uncertainty factor by the $\Sigma$ ESBTU. In this study, 16 PAHs were assessed and so there was need for adjustment. 13 PAH uncertainty factor (11.5) was selected, taking the level of certainty at $95 \%$ (table 5). If the adjusted $\Sigma$ ESBTU is less than 1, it is likely that the sediment will not be toxic to aquatic life. If greater than 1 then the sediment is toxic to aquatic life.

Table 5. PAH Uncertainty Factors.

\begin{tabular}{lll}
\hline Percentile & $\begin{array}{l}\text { 13 PAH uncertainty } \\
\text { factor }\end{array}$ & 23 PAH uncertainty factor \\
\hline 50 & 2.75 & 1.64 \\
80 & 6.78 & 2.8 \\
90 & 8.45 & 3.37 \\
95 & 11.5 & 4.14 \\
99 & 16.9 & 6.57 \\
\hline
\end{tabular}


- From: U.S. EPA's Procedures for the Derivation of Equilibrium Partitioning Sediment

Benchmarks (ESBs) for the Protection of Benthic Organisms: PAH Mixtures, Office of

Research and Development, November 2003, EPA/600/R02/013.

http://www.epa.gov/nheerl/publications/files/PAHESB.pdf

On multiplying the PAH uncertainty factor with the $\Sigma$ ESBTU, it was found that all the sediments at the different locations on the Lagos lagoon had their adjusted $\Sigma$ ESBTU below 1 and so were not toxic to aquatic life.

\subsection{Comparison of PAHs at Petrogenic and Pyrogenic Sources}

Comparing the PAH levels in this harbor location (petrogenic source) to those of Okobaba location (Pyrogenic source), most of the low molecular weight (2-3 rings) PAHs were as highly concentrated as the higher molecular weight (4-6 rings) PAHs in Okobaba sediments. In the harbor sediments the lower molecular weight PAHs were of much lower concentrations than the higher PAHs.

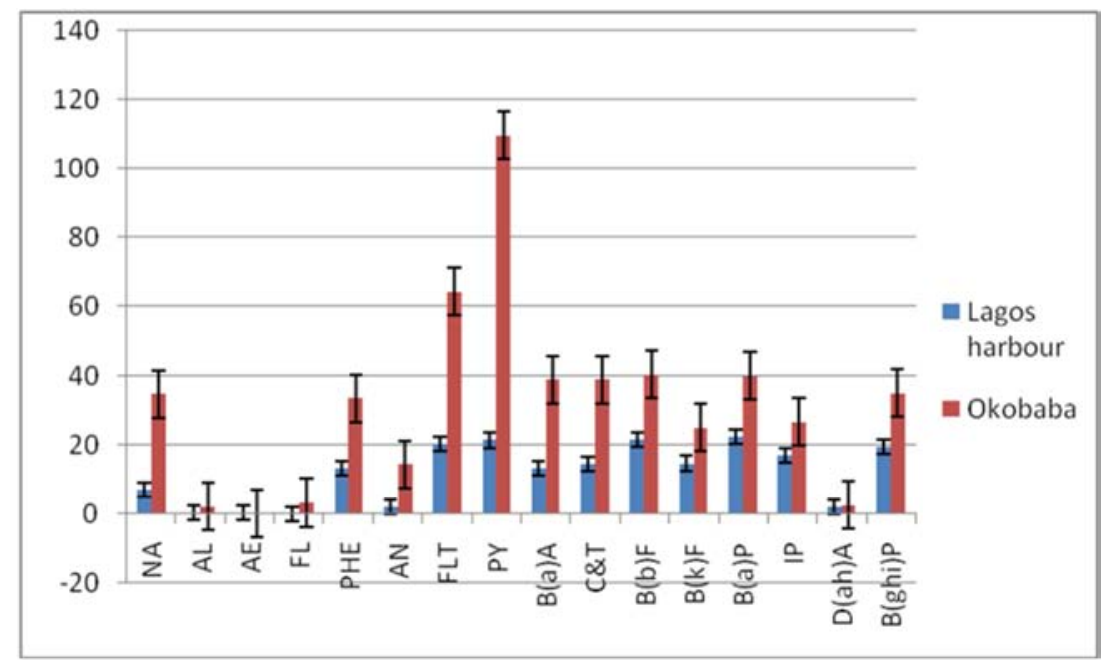

Figure 2. PAH Concentrations at Locations of Petrogenic and Pyrogenic Sources.

The contaminating PAHs that reside preferentially on the coal / wood particles are much more easily deposited at the location where it is generated (Okobaba) as the particles are much likely to sink directly and faster than oil would at the harbor. The oil at the harbor first of all spreads, and then gets emulsified, redistributed on the lagoon surface by either evaporation or dissolution and some are even degraded before some of it can stick to particulate matters and get deposited in the bottom sediment. In these processes most of the PAHs in the oil are transported from the harbor. This explains why the PAHs at the pyrogenic sources are higher in concentrations than those of petrogenic sources. At the Okobaba, pyrene had the highest concentration $(109.8 \mathrm{ng} / \mathrm{g})$ while at the harbor, benzo (a) pyrene had the highest $(22.40 \mathrm{ng} / \mathrm{g})$. This result is a confirmation that the occurrence and distribution of PAHs in the Lagos lagoon was largely a result of incomplete combustion (pyrogenic source).

\section{Conclusions}

The variation of sources of PAHs in Lagos lagoon due to the scattering of waste discharge and incineration points all over the city of Lagos; and also the draining of the city and its environs by a large number of water channels into the lagoon. All the 16 USEPA priority PAHs were distributed across the entire Lagos lagoon sediments. The occurrence and distribution of PAHs in the Lagos lagoon was largely a result of incomplete combustion (pyrogenic source).
Sediment PAH evaluation revealed PAHs pose no risk to aquatic life in Lagos lagoon but the presence of carcinogenic PAHs such as benzo (a) pyrene in dangerously high concentrations provided the basis for initial concern and a more detailed assessment of PAH - related risks to the Lagos lagoon aquatic ecosystem.

\section{References}

[1] Jassby, A. D., Cloern, J. E., Powell, T. M. (1993) Organic Carbon sources and Sinks in San Francisco Bay: Variability induced by River Flow. Mar. Ecol. Prog. Ser., 39-54.

[2] Neff, J. M., Wood J. Q., \& Gulbransen, T. C (1987) Recalculation of Screening Level Concentrations for non Polar Organic Contaminants in Marine Sediments (Final Report). Washington, D. C. Environmental Protection Agency.

[3] Nichols, F. H., Cloern, J. E., Luoma, S. N., Peterson, D. H., (1986). The Modification of an Estuancy. Science 231, $567-$ 573.

[4] Hostettler, F. D., Pereira, W. E., Kvenvolden, K. A., Van Geen A, Luoma, S. N., Fuller, C. C., Anima, R. (1999). A record of Hydrocarbon input to San Francicol Bay as traced by biomarker profiles in Surface Sediment and Sediment cores Marine Chemistry 64, 115-127.

[5] Davis, J. (2003), PAHs in Estuary. Regional Monitoring News, San Francisco Estuary Institute, Vol. 2, Issue 2, 1 $20 \mathrm{pp}$. 
[6] Ajao, E. A. (1996) Review of the state of pollution of the Lagos Lagoon. NIOMR Tech. Paper No. 106. 20.

[7] Yamamoto, K., Fukushima, M., Kakutani, N. \& Kuroda, K., (1997): Volatile Organic Compounds in Urban Rivers and their Estuaries in Osaka Japan. Environ. Pollut. Vol. 95 No. 1. pp. 135 - 143. Great Britain.

[8] Meador, J. P. et al (1995). Bioaccumulation of polycyclic aromatic hydrocarbons by Marine Organisms. Rev. Environ. Contam. Toxicol. 143, 79-165.

[9] Corbitt, R. A.(1998): Standard Handbook of Environmental Engineering $2^{\text {nd }}$ Edition. McGraw- Hill. New York.

[10] Van Metre, P. C., Manler, B. J. and Furlong, E. T. (2000): Urban Sprawl Leaves its PAH Signature. Eviron. Sci. Technol. Vol. 34, No. 19, 4064 - 4070.

[11] Hostettler, F. D., Rapp, J. B., Kvenvolden, K. A. \& Luoma, S. N. (1989) Organic makers as Source Discriminants and Sediment Transport Indicators in South San Francisco Bay, California Geochim. Cosmochim. Acta, 54, 1563-76.

[12] O’ Malley, V. P., Abrajano, T. A., Jr. Hellou, J (1994) Org. Geochem. 21, 809.

[13] Ghosh, U.; Cillette, S; Luthy, R. G.; and Zare, R. N. (2000) Microscale Location, Characterization, and Association of polycyclic Aromatic Hydrocarbons on Harbour Sediment particles. Environ. Sci. Technol. 34, 1729 - 1736.

[14] Howgate, P. Eleftheriou, A., Mclntyre, A. D., Mackie, P. R. Whittle, K. J. \& Farmer, J., (1977) Petroleum Tainting in Fish. This Volume pp. 143-6.

[15] Alani, R. A., Drouillard, K. G., Olayinka, K. O., and Alo, B. I (2013b). Bioaccumulation of Organochlorine Pesticide Residues in Fish and invertebrates of Lagos. Am. J. Sci. Ind. Res., 4 (1): 22-30 ISSN: 2153-649X, doi: 10.5251/ajsir.

[16] Long, E. R., (1992). Ranges in Chemical Concentrations in Sediments Associated with Adverse Biological Effects. Mar. Poll. Bull. 24, $38-45$.

[17] MacDonald, D. D., Carr, R. S., Calder, F. D., Long, E. R., \& Ingersoll, C. G. (1996). Development and Evaluation of Sediment Quality Guidelines for Florida Coastal Water. Ecotoxicology, 5, $253-278$.

[18] Walker, C. H. (2009). Organic Pollutants. An Ecotoxicological Perspective. New York. CRC Press, 414p.
[19] Swartz, R. C. S Chultz, D. W., Ozretich, R. J., Lamberson, J. O., Cole, F. A. Dewitt, T. H., Redmond, M. S., \& Ferraro, S. P. (1995). PAH: a model to predict the toxicity of polynuclear aromatic hydrocarbon mixtures in field collected sediments. Environ Toxicol. Chem., 11, 1567-1581.

[20] Alani, R. A., Olayinka, K. O., and Alo, B. I (2013c) Studies on Persistent Organic Pollutants (POPs) in the Lagos Lagoon 1: Occurrence and Levels of Polycyclic Aromatic Hydrocarbons (PAHs) In Surface Waters of the Lagoon. Journal of Emerging Trends in Engineering and Applied Sciences (JETEAS) 4 (6): 811-818. ISSN: 2141-7016.

[21] Lazar R, Edwards RC, Metcalfe CD, Metcalfe T, Gobas FAPC, Haffner GD. 1992. A simple, novel method for the quantitative analysis of coplanar (nonortho substituted) polychlorinated biphenyls in environmental samples. Chemosphere 25: 493-504.

[22] Alani, R. A., Drouillard, K. G., Olayinka, K. O., and Alo, B. I (2012a) Bioaccumulation of Polycyclic Aromatic Hydrocarbons (PAHs) in Fish and invertebrates of Lagoon, Nigeria. Journal of Emerging Trends in Engineering and Applied Sciences (JETEAS) 3 (2): 287-296. ISSN: 21417016.

[23] Pazdro, K. (2002) Persistent Organic Pollutants in Sediments from the Gulf of Gdańsk. Institute of Oceanology, Polish Academy of Sciences, Sopot.

[24] Bartle, K. D., Creaser, C. \& Purchase, R. (1991) Food Contaminants, Sources and Surveillance. The Royal Society of Chemistry, Cambridge, 41.

[25] Potrykus, J., Albalat, A., Pempkowiak, J. \& Porte, C. (2003) Content and pattern of organic pollutants (PAHs, PCBs and DDT) in blue mussels (Mytilus trossulus) from the southern BalticSea*. OCEANOLOGIA 45, 337-355.

[26] CCME (1999) Canadian sediment quality guidelines for the protection of aquatic life: Summary tables. In: Canadian environmental quality guidelines, 1999, Canadian Council of Ministers for the Environment, Winnipeg.

[27] Cole, S., Codling, I. D., Parr, W. and Zabel, T. (1999) Guidelines for managing water quality impacts within UK European marine sites. Prepared by: WRc Swindon Frankland Road Blagrove Swindon Wiltshire SN5 8YF, 13-109.

[28] Varanasi, U., Gmur, D. J. \& Rechert, W. L. (1981) Effect of environmental temperature on naphthalene metabolism by juvenile starry flounder (platichthys sllelatus). Arch. Environ. Contam. Toxicol., 10, 203-214. 